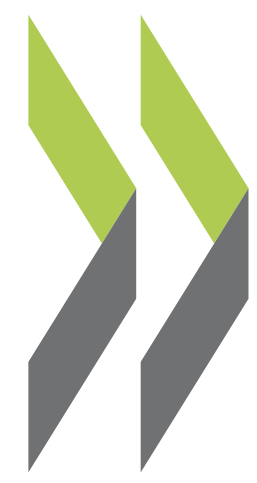

OECD Economics Department Working Papers No. 1193

\title{
Improving Transport Infrastructure in Russia
}

\section{Alexander Kollk, \\ Artur Radziwill, \\ Natalia Turdyeva}

https://dx.doi.org/10.1787/5js4hmcs3mxp-en 


\section{Unclassified}

ECO/WKP(2015)11

Organisation de Coopération et de Développement Économiques

Organisation for Economic Co-operation and Development

25-Mar-2015

ECONOMICS DEPARTMENT

English - Or. English

IMPROVING TRANSPORT INFRASTRUCTURE IN RUSSIA

ECONOMICS DEPARTMENT WORKING PAPERS No. 1193

By Alexander Kolik, Artur Radziwill and Natalia Turdyeva

OECD Working Papers should not be reported as representing the official views of the OECD or of its member countries. The opinions expressed and arguments employed are those of the author $(s)$.

Authorised for publication by Robert Ford, Deputy Director, Country Studies Branch, Economics Department.

All Economics Department Working Papers are available at www.oecd.org/eco/workingpapers

JT03373081

Complete document available on OLIS in its original format

This document and any map included herein are without prejudice to the status of or sovereignty over any territory, to the delimitation of international frontiers and boundaries and to the name of any territory, city or area. 
OECD Working Papers should not be reported as representing the official views of the OECD or of its member countries. The opinions expressed and arguments employed are those of the author(s).

Working Papers describe preliminary results or research in progress by the author(s) and are published to stimulate discussion on a broad range of issues on which the OECD works.

Comments on Working Papers are welcomed, and may be sent to OECD Economics Department, 2 rue André-Pascal, 75775 Paris Cedex 16, France, or by e-mail to eco.contact@oecd.org.

This document and any map included herein are without prejudice to the status of or sovereignty over any territory, to the delimitation of international frontiers and boundaries and to the name of any territory, city or area.

The statistical data for Israel are supplied by and under the responsibility of the relevant Israeli authorities. The use of such data by the OECD is without prejudice to the status of the Golan Heights, East Jerusalem and Israeli settlements in the West Bank under the terms of international law.

\section{(C) OECD (2015)}

You can copy, download or print OECD content for your own use, and you can include excerpts from OECD publications, databases and multimedia products in your own documents, presentations, blogs, websites and teaching materials, provided that suitable acknowledgment of OECD as source and copyright owner is given. All requests for commercial use and translation rights should be submitted to rights@oecd.org 


\section{ABSTRACT/RÉSUMÉ \\ Improving Transport Infrastructure in Russia}

Transport can play an important role in promoting growth, diversification and regional convergence. However, with insufficient investment and incomplete structural reforms, Russia faces very large challenges in modernising its large transport system. Urban transport problems are intensifying, because of weak policy coordination and inadequate traffic management. Promoting competition in the transport sector is essential, in particular by effectively opening the railway freight market to independent operators.

This Working Paper relates to the 2013 Economic Survey of the Russian Federation (www.oecd.org/eco/surveys/economic-survey-russian-federation.htm).

JEL Classification: transport, infrastructure, traffic management, competition, environmental standards, safety standards.

Keywords: H54, L4, L9, O18, R4

\section{Améliorer les infrastructures de transport en Russie}

Les transports peuvent jouer un rôle important dans la promotion de la croissance, la diversification et la convergence régionale. Cependant, du fait d'un niveau insuffisant d'investissements et de réformes structurelles incomplètes, la Russie doit faire face à de très grands défis afin de moderniser son système de transport. Les problèmes de transport urbain s'intensifient en raison de la faible coordination des politiques et d'une gestion inadéquate du trafic. Promouvoir la concurrence dans le secteur des transports est essentiel en particulier via l'ouverture effective du marché du fret ferroviaire aux opérateurs indépendants.

Ce document de travail se rapporte à l'Étude économique de l'OCDE 2013 sur la Fédération de Russie (www.oecd.org/fr/eco/etudes/etude-economique-russie.htm).

Classification JEL : transports, infrastructures, gestion du trafic, concurrence, normes environnementales, normes de sécurité.

Mots clés : H54, L4, L9, O18, R4 


\section{TABLE OF CONTENTS}

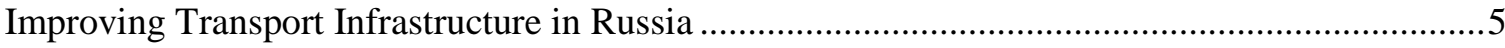

Transport bottlenecks hamper growth and regional convergence.............................................5

Prioritisation and implementation capacity are the keys to success of infrastructure renewal .7

Ensuring competition in the transport sector....................................................................10

Establishing and enforcing appropriate standards is important for safety and environmental

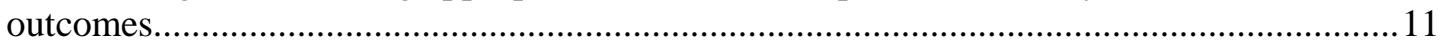

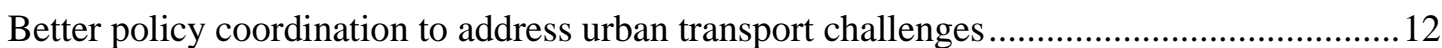

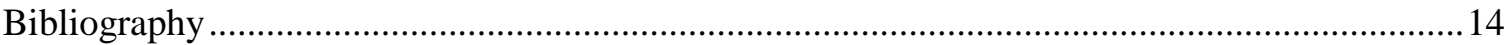

Annex 1.A1. Economic impact of improving transport infrastructure in Russia: results of the computable general equilibrium model

\section{Tables}

1. Transport infrastructure networks scale comparison, 2009

\section{Figures}

1. Competitiveness and quality of transport infrastructure .6

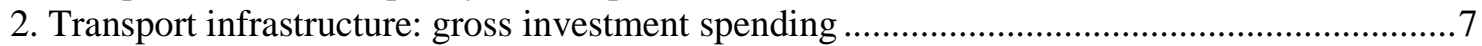

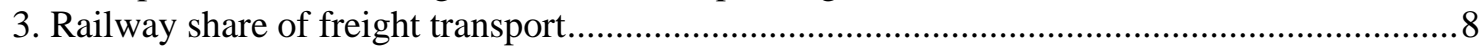

4. Average traffic speed in peak hours in selected cities ..........................................................

\section{Boxes}

Box 1. Transport Strategy of the Russian Federation until 2030 ...............................................

Box 2. Recommendations for improving transport infrastructure ............................................13 


\title{
IMPROVING TRANSPORT INFRASTRUCTURE IN RUSSIA
}

\author{
By Alexander Kolik, Artur Radziwill and Natalia Turdyeva ${ }^{1}$
}

\section{Transport bottlenecks hamper growth and regional convergence}

Transport can play an important role in promoting growth, diversification and regional convergence in Russia. It is a backbone industry that enables participation in global production chains, which have been productivity a driver in many countries. Improvement in transport sector efficiency by $10 \%$ could increase overall GDP by $0.8 \%$ according to a general equilibrium model of the Russian economy (Annex A1). The same model also demonstrates that increased efficiency would play a particularly strong positive role in poorer regions, such as in the South, Siberia and the Far East. The impact on manufacturing will also be stronger than on extractive industries. As a demonstration of the importance of transport for economic growth, freight turnover (ton-kilometres) has increased by roughly two thirds in Russia since 1998 and has recently exceeded its turnover at the time of the collapse of the Soviet Union.

Russia faces very large challenges in modernising its transport system, which it is among the largest in the world (Table 1). According to the World Economic Forum, the ranking of Russian transport sectors among 148 countries is generally poor (Figure 2). It is also rather uneven: in the case of quality of railways, Russia's rank is 31, and for roads 136, air transport 102 and ports 88 (World Economic Forum, 2013). The transport network accessibility is also very uneven geographically. It is densest in the European part of Russia, while some areas in Siberia and the Far East lack regular connections with the main transport network, implying an important barrier to economic development of these regions. One third of all rural settlements are still not connected with the national paved road network.

1. Alexander Kolik is at the National Research University Higher School of Economics (HSE) in Moscow, Artur Radziwill was senior economist at the Economics Department of the OECD in Paris and Natalia Turdyeva is at the Centre for Economic and Financial Research (CEFIR) in Moscow. This paper was originally produced and published as part of the chapter "Improving the business climate and transport infrastructure in Russia" of the 2013 OECD Economic Survey of the Russian Federation published in January 2014 on the responsibility of the Secretary General of the OECD. The authors would like to thank the Russian authorities, as well as Andrew Dean, Bob Ford, Andreas Wörgötter, Lilas Demmou, Stephen Perkins and Kurt van Dender, as well as members of the EDRC for valuable comments and discussions. The authors would also like to thank Corinne Chanteloup for statistical assistance. 
Table 1. Transport infrastructure networks scale comparison, 2009

Thousand $\mathrm{km}$

\begin{tabular}{lrrrr}
\hline & EU27 & USA & CHINA & RUSSIA \\
\hline Roads & 5000 & 4400 & 3056 & 776 \\
Railways & 212 & 202 & 86 & 86 \\
Inland waterways & 41 & 41 & 117 & 102 \\
\hline
\end{tabular}

Source: European Commission, EU Transport in Figures, Statistical Pocketbook, 2012.

Figure 1. Competitiveness and quality of transport infrastructure

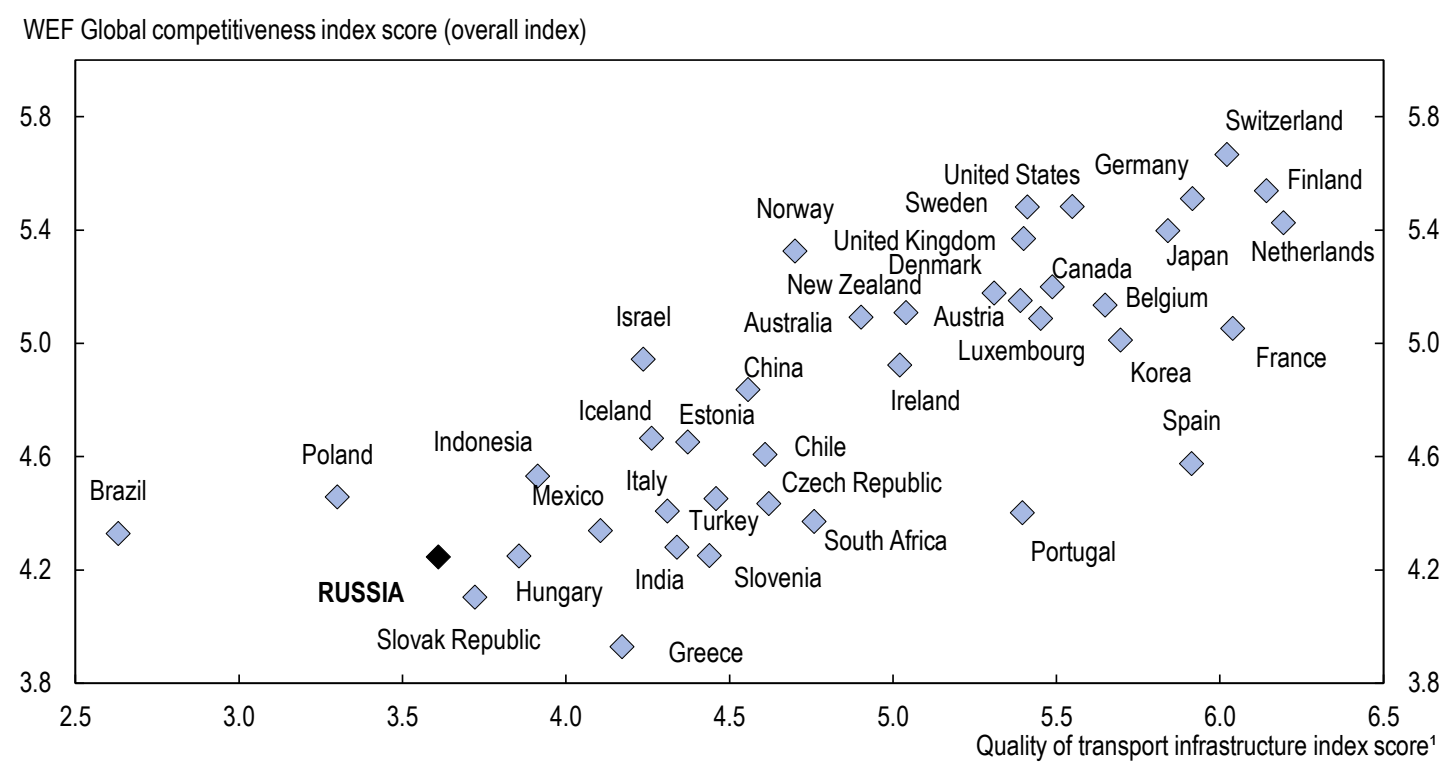

1. Simple average of four quality indicators (roads, railroad infrastructure, port infrastructure, air transport infrastructure). The responses are to the questions : "In your country, how would you assess the following aspects of transport infrastructure? a) Roads b) Railroad system c) Air transport infrastructure $d$ ) Seaport facilities [1 = extremely underdeveloped - among the worst in the world; 7 = extensive and efficient - among the best in the world].

Source: World Economic Forum (2013), The Global Competitiveness Report 2013-14.

Priorities, principles and the main directions of the transport system development are presented in the "Transport Strategy of the Russian Federation until 2030", which was elaborated in 2008 a revised version being approved by the government in August 2013. The Strategy proposes appropriate policy directions (Box 1.2) and the authorities are now rightly placing it more clearly at the centre of decision making. In particular, the key multi-year federal financing programme (State Programme "Development of Transport System") seems to be now well synchronised with the Strategy. This should link investments with long-term priorities more strongly than in the past, and minimise the influence of short-term political and budgetary considerations, bringing more coherence and prioritisation to policy making. Regional transport strategies currently in preparation should complement the integrated system of strategic planning in Russia. 


\section{Box 1. Transport Strategy of the Russian Federation until 2030}

The Strategy defines strategic goals for the state policy in the transport sector:

- $\quad$ creating the integrated transport space in the Russian Federation;

- $\quad$ ensuring access to quality transport-logistic services;

- $\quad$ ensuring access to quality transport services for the population;

- integration into the international transport system, increasing the transport services exports and transit;

- $\quad$ increasing the level of transport safety;

- $\quad$ reducing the negative environmental impact of transport.

Implementation mechanisms include:

- the introduction of the national and regional high-level plans to coordinate national or regional transportation demand and supply;

- $\quad$ formation of the multi-annual guaranteed transport financing system;

- creation of the monitoring system on transportation markets and transport infrastructure;

- development of the PPP mechanisms;

- Improvement of the legal base of the transport industry.

The strategy provides a detailed list of targeted numeric objectives in term of social, economic, and transportsector specific results.

Source: Ministry of Transport (2012).

\section{Prioritisation and implementation capacity are the keys to success of infrastructure renewal}

Recent years have been marked by the growing attention of the government to the development of transport infrastructure, as reflected in massive increases in spending on rail and roads (Figure 2). According to the existing plans, this trend will be continued at least until the end of the decade.

Figure 2. Transport infrastructure: gross investment spending

Current prices and exchange rates, billion euros

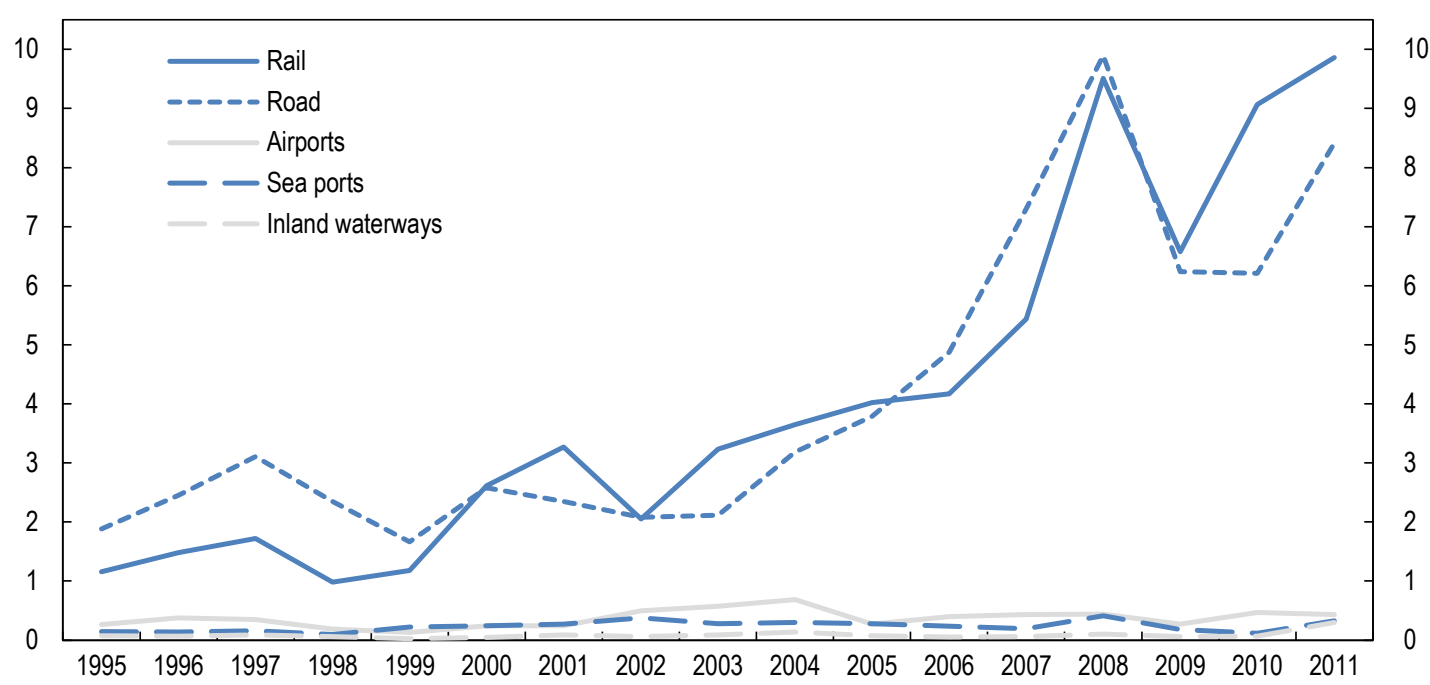

Source: OECD/ITF (2013), Spending on Transport Infrastructure 1995-2011. 
Improving the quality of railway infrastructure is particularly important as railways dominate freight transport (Figure 3) and serve large Russian industries, notably raw materials, which often have no transport alternative. While Russia has inherited an extensive railway system, repairs do not keep up with infrastructure degradation and increasing freight transport demand (IERT, 2012), which manifests itself most strongly in insufficient capacity of particular sections on the main export directions. The total length of sections with capacity lower than demanded was roughly 7600 kilometres (9\% of total railways length) in 2012 and under current trends will reach 13000 kilometres in 2015. Official plans aim at reducing bottlenecks to $5.1 \%$ of the total length by 2020 , and to extend the network by $3 \%$. But in the past similar targets have been systematically missed.

\section{Figure 3. Railway share of freight transport}

$2010, \%$ in total inland freight tonne-km

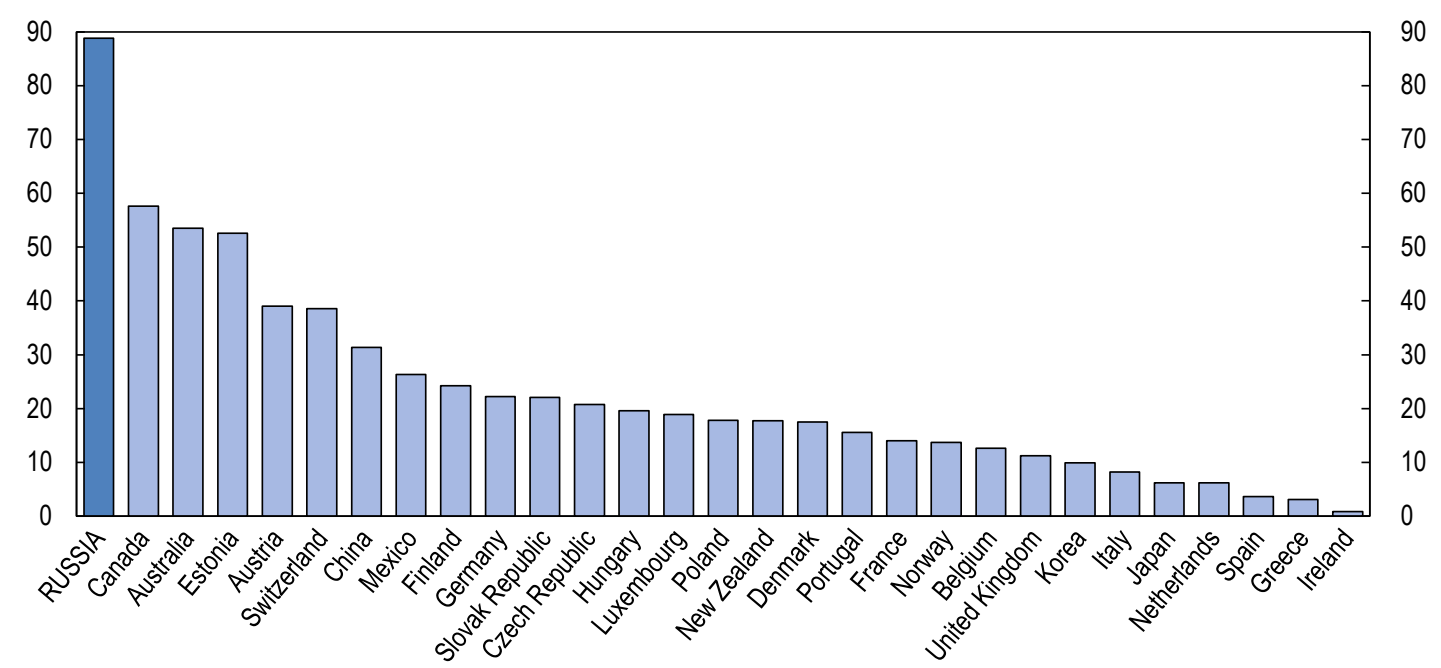

Note: Excluding oil and gas pipelines. 2009 data for Canada, China, Greece, Luxembourg, Switzerland. 2008 for Australia, Korea, New Zealand, United Kingdom.

Source: OECD/ITF (2012), Trends in the Transport Sector 1970-2010.

Railways also remain essential in long-haul passenger transport serving more than $40 \%$ of all passengers. Improving transport connectivity among major cities through the construction of the high-speed railway (HSR) has also long been an important item on the policy making agenda. The first HSR programme was approved in 2006 and envisaged 21 HSR routes being built till 2020. Plans to build an HSR between Moscow and Kazan were included in the July 2013 stimulus programme. Extensions to Yekaterinburg and the route between Moscow and St. Petersburg are also being considered.

The road system was underdeveloped in the Soviet times, as this sector was seen to play a secondary role in the centrally planned and heavily industrialised economy. But the role of road transport has been growing rapidly since the start of the economic transition and the marked acceleration in investment has made road freight competitive with rail in many markets where rail enjoyed a monopoly. But despite the growing attention of the government to the development of the road network, its density and quality still do not meet the needs of rapidly increasing motorisation. There are many overloaded sections on the main federal roads - generally near big cities, and especially within the Moscow zone. The majority of roads are not adapted to heavy vehicles: less than $30 \%$ of federal and regional roads are adapted to standard modern axle loads of 10 tonnes or more. Modernisation is therefore very important and road components for the main corridors should be designed in line with international corridors and to be usable for the most 
efficient lorries. The State Programme aims to ensure that all federal roads will be of satisfactory quality by 2019 . Heavy investments are also planned at regional and local levels.

While air passenger traffic is increasing, airport infrastructure, with the exception of the biggest airports, is underfinanced. The smaller airports were transferred to the regions which often cannot finance them properly and many were closed or face bankruptcy. Such outcomes are worrying for more distant regions, where there are no feasible alternatives to air connections. The existing regional and local subsidisation system is non-transparent and ineffective and needs to be revised. However, several programmes providing funding for socially important routes have been implemented recently. While infrastructure is being expanded and repaired, improving the efficiency of existing infrastructure is also important. For example, the number of take-off and landing operations per runway in Moscow airports - the busiest in Russia - is currently less than half than in London airports and two-thirds of that in some Chinese airports (Katchan, 2011). Airport infrastructure development therefore needs to be coordinated with the air-traffic management system improvements, which would also allow for increasing the total capacity of air routes within Russia (Okulov, 2011).

Massive investment in seaports increased total port capacity above the current and medium-term needs. However, bottlenecks in the inter-modal infrastructure limit the effective use of ports (Rosmorport, 2012). Most ports suffer from poor rail and road access and lack of modern logistic facilities providing smooth trade and transport flows. There is also a lack of specific port capacities serving trade in highprocessed goods, first of all in containers and wheeled cargo, since most investments were attracted to projects linked to exports of raw materials. Customs and other border-crossing procedures still take a lot of time and the "single window" principle has not been implemented in the seaports in spite of numerous projects. Therefore, while high private sector participation in port development is a major achievement, the authorities should play a more active role in strategic planning and coordination.

While investment needs are very high as reflected in long-term spending plans, so are policy planning and implementation capacity challenges. Strict prioritisation according to transparent indicators will not only be necessary for new projects, but also for maintenance and modernisation of existing infrastructure. As part of the modernisation of legislation in the field of road infrastructure, the full implementation of the principle of normative financing for the repair and maintenance of roads is foreseen by law in 2014. The high capital and running costs of transport infrastructure projects deserve elaborate cost-benefit analysis, covering the lifetime of a project and including all external costs and benefits.

It is equally important to seek to prioritise "smart" solutions and efficiency improvements to maximise the benefit from using existing infrastructure. For example, intermodal solutions could be used instead of parallel roads and railways; improved management of road capacity through congestion and parking pricing could reduce the need for building new city roads; and new air traffic management systems could reduce the need for new airport runways. This would require, among other things, improving the quality of the transport statistics on the basis of modern market monitoring methods. In particular, there is only limited statistical information available about road freight transport and coach passenger transportation, while no reliable statistics are available on private passenger car usage.

The implementation of large-scale infrastructure investment projects, such as the recently announced construction of a high-speed rail line between Moscow and Kazan, a central ring road around Moscow and upgrading the Trans-Siberian and Baikal-Amur railways, in cost-effective fashion will be challenging. The new law on public procurement, which increases transparency and openness at all stages of the procurement process is an important step forward but needs to be supported by further improvements in project evaluation, management and control, better use of the public-private partnership and, mostly crucially, cleaning up corruption (see above). 


\section{Ensuring competition in the transport sector}

Ambitious and wide-ranging railway reform was started in 2001 but is yet to be fully completed. In its first stage (2001-03) the functions of the state regulation were separated from operations, which previously were all combined within the Railway Ministry. The state-owned company "Russian Railways" (RZD) was established in 2003 and the regulatory part was integrated within the Ministry of Transport. In the second stage (2003-05) RZD spun off 40 daughter companies operating specialised rolling stock (container wagons, reefers, car-carriers, etc.) and providing special services. In the third stage (2006-10), massive private investments were allowed into rolling stock so that currently about $80 \%$ of freight turnover is transported by freight wagons owned by private wagon operators. However, only RZD is allowed to operate locomotives and hence it retains an effective monopoly in freight carriage. Any attempts by private players to enter this market (with 200 licences issued so far), have been effectively blocked. The system is also legally closed for foreign operators.

This continued monopoly combined with disintegration of the wagon operation leads to an ineffective use of assets with thousands of empty wagons, thereby creating additional railway bottlenecks, excessively long shipping times (for example guaranteed delivery time between Krasnoyarsk and St. Petersburg is usually not shorter than 30 days) and even denial of service. The average speed of freight trains fell from 274 kilometres per day in 2010 to 219 in 2012 (Nord-News, 2013). Tariffs continued to rise rapidly in recent years. All these problems make it very difficult for many firms, especially SMEs, to ship goods by rail. According to the 2011 government decision, RZD is expected to solve problems with the management of independent wagons before the current market structure is further reformed. But meanwhile RZD was frequently fined by the Federal Anti-Monopoly service for abusing its market position, and in particular for refusing to provide freight wagons to other carriers. However, these sanctions have proved largely ineffective so far, and the head of FAS publicly characterised RZD in July 2013 as a "typical Soviet monopoly" operating "at the expense of its customers".

A genuine reform that would introduce competition into railway freight is therefore essential. There are two principal approaches to such reform as practised across OECD countries: allowing competition among the vertically-integrated railway companies or unbundling the infrastructure from train operations to establish the platform for competition between separate companies running trains. The decision to choose and implement the targeted model of railway competition needs to take into account important features of the Russian rail freight system: intensive usage of infrastructure and its concentration on a few key lines. Nevertheless, the decision is long overdue and would require a wide-ranging legal and regulatory reform, as well as strengthened competition rules enforcement. Whatever is the decision, carefully managed tariff liberalisation will be needed to better align tariffs with costs and allow rail freight to compete successfully against road transport for higher value cargos. Unfortunately, neither the fourth stage of reform announced in 2011 nor the strategic transport documents signal any progress in this area. While there are conflicting announcements concerning plans for partial privatisation of RZD, privatisation alone is unlikely to improve transport outcomes given the current market structure. In fact replacing a public monopoly with a private monopoly might make the situation even worse. 
Long-haul railway passenger transport is also highly monopolised. The Federal Passenger Company (FPK), a daughter company of RZD, controls more than $95 \%$ of the market, and RZD controls an additional $3.5 \%$ of the market. The rest is divided between small private companies, each operating a limited number of routes (FPK, 2012), FPK faces competition only on the route between Moscow and St. Petersburg. Promoting more active competition in long-haul passenger transport should therefore be another priority for Russian policymakers. This is likely to be in the form of competition on the tracks in more profitable markets and in the form of competition for exclusive concessions in markets, which require subsidisation.

There are also barriers to competition in air transport, which is important considering the size of the country and the poor quality of railway and road infrastructure. Although the air carriage market is generally very competitive, the main problem is linked to the slow pace of providing non-discriminatory access to ground services (fuelling, technical services, etc.) resulting in poor quality and high prices. This is because the legal base regulating the relationship between the carriers and the airports is not properly developed, and in some regions, airport and air carriage business have not been separated. As a result, prices for aircraft fuel are usually higher than in other countries, and other airport services are twice as expensive (Fridland, 2013). In consequence, import-bound air cargo traffic is frequently arranged via the neighbour states' airports with the final leg to Russia provided by trucks. High technical landing and airnavigation fees also limit the growth potential of international transit cargo. It is therefore important to finalise separation between airport and airlines, better regulate local monopolies and strengthen competition policy enforcement. The lack of small airports with good and affordable service quality poses barriers for low cost carriers (Sobol, 2012). Low-cost carriers also face legal obstacles, as according to the Aviation Code of Russia the carrier is obliged to provide the full scope of passenger services (on-board meals, baggage handling, etc.) without any exceptions. Removing such barriers would be important to encourage a low-price segment for passenger air transport after low-cost carriers left the market in 2011.

\section{Establishing and enforcing appropriate standards is important for safety and environmental outcomes}

A deficit of modern and systematically enforced standards for road transport is another key problem contributing to road safety, environmental and service quality concerns:

- Transport safety is a serious problem. Road traffic mortality is five times higher than in several European Union countries, about twice higher than in the United States and significantly higher than in other advanced transition economies. The bad state of the roads, a sharp decline in road police personnel, as well as drunk driving, are contributing factors (HSE, 2013). Strengthening standards and enforcement should therefore be considered. The unsatisfactory condition of emergency medical services in some regions exacerbates the situation.

- The environmental impact of road transport is substantial. Its share in all the emissions in Russia is about $40 \%$ and in transport emissions about 80\% (MNRE, 2012). The total volume of emissions is decreasing despite the growing number of vehicles, because the car fleet is gradually being replaced with lower emission vehicles. Also, after several delays, more ambitious mandatory fuel efficiency standards for cars and trucks have been introduced: Euro 3 fuels are required from 1 January 2013 and Euro 4 fuels will be required from 1 January 2015. However, the motor fuel quality monitoring and enforcement system remains ineffective, and about one third of all the motor fuel sold in Russia still does not comply even with Euro 2 (Dieselnet, 2013). Proposals of tax changes encouraging the use of natural gas in transport are being discussed, but have not yet been adopted.

The virtual abolition of vehicle technical inspections in 2012, introduced in an attempt to cut red tape, has had an important negative impact on the enforcement of transport safety and environmental standards. 
The technical inspection of road vehicles in Russia, which was traditionally implemented by the road police, is currently within the responsibility of the Russian Union of auto-insurance companies. An insurance policy cannot be sold without the technical inspection card, but in practice, the insurance companies often ignore this rule, and no state control or enforcement is envisaged at the moment (AUTONEWS-RU, 2013).

\section{Better policy coordination to address urban transport challenges}

Local transport constraints mean that it is increasingly difficult to attract new investment and workers to the fastest growing cities. Traffic congestion, long commuting times and related air pollution are becoming key challenges in almost all bigger cities, but the situation is particularly bad in Moscow and St. Petersburg (Donchenko, 2013). Hours-long traffic jams have become the norm and the average traffic speed in peak hours in Moscow is much lower than in other European capitals (Figure 1.10), generating high congestion costs.

The main factor influencing the urban transport situation is the motorisation boom in Russia. Car ownership has doubled since 2000. While the average car ownership in Russia is currently about 250 cars per 1000 inhabitants, it is much higher in urban areas. The share individual transport by private cars is estimated at $68 \%$ which is still less than in most OECD countries and hence is likely to grow further. This suggests that without appropriate policy response, urban transport problems will only become more acute.

The current policy priority is to improve the quality and accessibility of the public urban transport (Donchenko, 2013). Finalising the reform of local railways is essential for improving the quality of suburban commuting, as railways serve $44 \%$ of local public transport users. The "Concept of the Local Passenger Railway Services", drafted at the end of 2012, is aimed at modernising railways and integrating them with other elements of urban transport infrastructure, by establishing clear mechanisms of subsidising the suburban carriers; setting quality standards; and mandating regional transport service development plans. However, the draft legislation is not prepared yet.

While the bus is the main mode of urban public passenger transportation in Russia, it is becoming less attractive as weak municipal finances have led to rapid ageing of the bus fleet (MOT, 2012a). The recent federal support for modernising the public transport fleet is a therefore step in the right direction. The attractiveness of buses and trolleybuses is further reduced by the fact that they are usually not privileged in traffic organisation, and hence offer little advantage over cars. In the course of the reforms the public transport system has been complemented by mini-buses, operated by individuals or by small private enterprises. They now serve up to 15\% of all the urban passengers (MOT, 2012b). This subsector is poorly regulated in terms of quality standards and is not at all integrated with the rest of the transport system. On the other hand, the current legal framework does not allow private operators in the mainstream urban public transport system. The existing legal frameworks, including federal anti-monopoly law, should be revised to eliminate the legal barrier to transparent and competitive contracting of public transport services. 
Figure 4. Average traffic speed in peak hours in selected cities

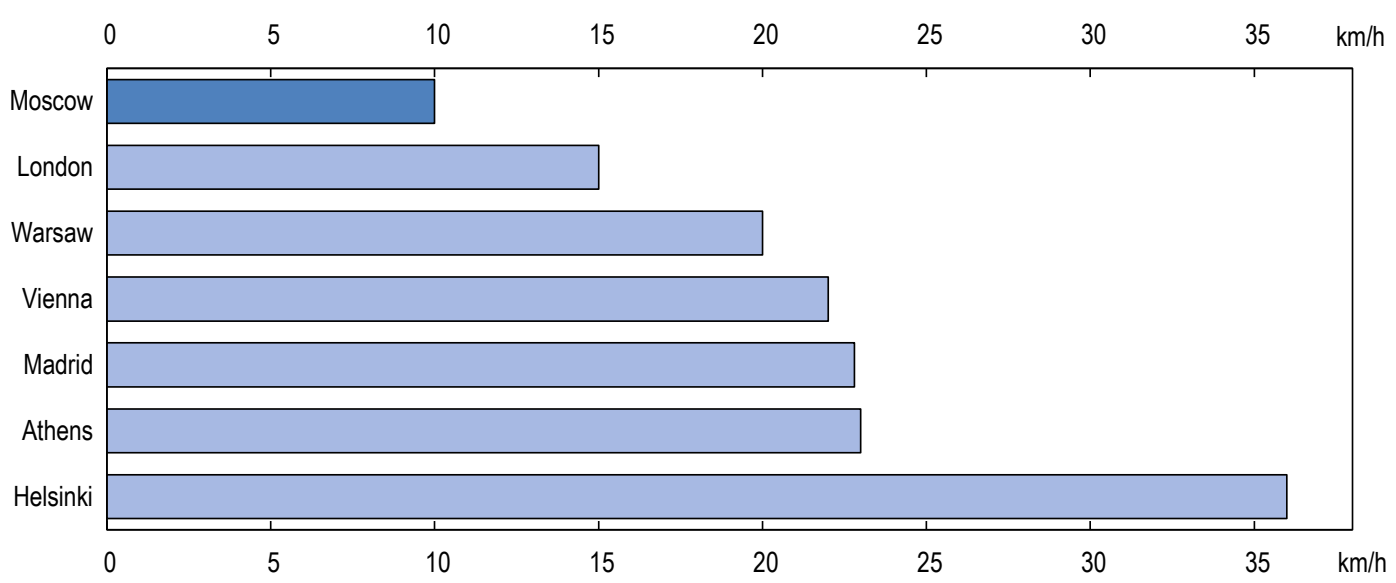

Source: Donchenko, V. (2013), "Towards the Sustainable Mobility in Russian cities: problems, challenges and risks", paper presented at the he International symposium OPTOSOZ, Moscow, 14 March.

There is scope to improve traffic management. City authorities try to tackle the problem by introducing dedicated lanes for buses, bicycle paths and pedestrian zones, prohibition of heavy vehicle traffic, strict parking policies, etc. But these measures are usually uncoordinated, not supported by economic incentives and generally ineffective (Donchenko, 2013). Transport policy planning is heavily focused on investment projects. Moreover, there is no proper coordination among various authorities and the link with city development planning is weak. As in other countries congestion charges are unpopular and would occupy considerable political capital.

Introducing special federal legislation concerning urban public transport organisation, management and financing, should be a key priority. Russian regions have tried to introduce such models within the framework of regional laws but their attempts have come into conflict with general federal antimonopolistic legislation. The federal government, however, could develop a menu of model urban and region transport plans, which would be available to the local authorities, together with ready-to-use legal instruments, for example for transport service contracting. Such framework legislation should be accompanied by measures improving the quality of local level policy planning, for example by establishing a national centre to train the staff and elaborate recommendations based on best international and Russian practices.

\section{Box 2. Recommendations for improving transport infrastructure}

\section{- Tackle transport bottlenecks}

- Ensure that Transport Strategy provides a clear and binding guidance to executive documents.

- Prioritise, when possible, maintenance and modernisation of existing infrastructure over large and expensive new construction projects.

- Prioritise "smart" solutions, intermodal complementarities and efficiency improvements to minimise investments needs.

- Improve the quality of transport statistics related to road freight transport, coach passenger transportation, and in particular to private passenger car usage. 
- Improve the efficiency of transport infrastructure spending.

- Fight corruption in the implementation of large investment projects.

- Improve evaluation methodologies.

- Improve the legal framework to increase the use of public private partnerships.

- Promote competition in the transport sector.

- Choose and start implementing a preferred model of competition in railway freight transport.

- Stimulate on tracks competition and competition for exclusive concession in passenger train transport.

- Finalise separation between airlines and airports and remove legal barriers for low-cost operators.

- Strengthen standards and their enforcement to minimise the health and environmental impact of transport.

- Ensure better policy coordination to address urban transport challenges.

- Finalise the reform of local railways to allow for integration with other elements of urban transport infrastructure.

- Improve transport demand and traffic management, including by introduction of congestion charges and strict parking policies.

- Develop a modern legal framework for integrated urban transport planning, removing obstacles for contracting private transport operators.

- Better coordinate transport policies with territorial development planning.

\section{BIBLIOGRAPHY}

AUTONEWS-RU (2013), "Voditelam ne Pridetsa Prohodit Tehosmotr" (Drivers will not have to pass the inspection), http://autonews.ru/autobusiness/news/1720780/.

Dieselnet.Com (2013), Emission Standards Russia, http://dieselnet.com/standards/ru/.

Donchenko, V. (2013), "Towards the Sustainable Mobility in Russian cities: problems, challenges and risks", paper presented at the he International symposium OPTOSOZ, Moscow, 14 March.

EBRD (2012), Diversifying Russia. Harnessing regional diversity, European Bank for Reconstruction and Development, London.

FPK (2012), The 2011 Yearly Report, Federal Passenger Company, Moscow.

Fridland, A. (2013), "O structure Zatrat na Aviaperevozki I Effektivnosti predlagaemih Mer" (On the Air Transportation Costs Structure and the Effectiveness of the Proposed Measures), presentation to the Transport Union of Russia, Moscow.

GEM (2012), GEM 2012 Global Report, Global Entrepreneurship Monitor. 
HSE (2013), "Bezopasnost dorozhnogo dvizhenia v Rossii:Sovremennoe Sostoyanie I Neotlozhnie Meri po Ulucheniu Situacii" (Road Safety in Russia: Current Situation and Emergent Measures for its Improvement", Higher School of Economics, Moscow.

ICD (2013), Survey of public opinion, Institute of Contemporary Development.

IERT (2012), The Reference and Analytical Paper on the Railway Infrastructure Development in the Regions of the Russian Sea Ports Until 2015, The institute of the transport economics and development, Moscow.

IUR (2012), 2012 Report on Combined transport in Europe, International Union of Railways, Paris.

Katchan, V. (2011), Tri voprosa $k$ ministru transporta Rossii (Three Questions to the Russian Minister of Transport), ATO (Aviation Business Review Portal), http://ato.ru/content/tri-voprosa-k-ministrutransporta-rossii, accessed May, 2013.

Korostelev, V. (2012), “Odno Okno - Neverny Princip Kotori ne Rabotaet” (One window - the wrong principle that does not function).

Lehmann, H. and M. Silvagni (2013), "Is There Convergence of Russia's Regions? Exploring the Empirical Evidence: 1995-2010", Economics Department Working Papers, No. 1083, OECD Publishing, doi: $10.1787 / 5 \mathrm{k} 422105 \mathrm{ht} 33$-en.

MNRE (2012), The State Report on the Environment condition and the Environment protection in 2011, Ministry of Natural Resources and Environment of the Russian Federation.

MOT (2012), Transportnaya Strategia Rossiiskoi Federacii na Period do 2013 Goda (Transport Strategy of the Russian Federation until 2030), MOT, Moscow.

MOT (2012a), Ob Osnovnych Itogah Socialno-Economicheskogo Razvitia Transportnogo Kompleksa v 2011 Gody i zadachah na 2012 god I Srednesrochnuiu Perspektivu do 2014 Goda (On the main results of the socio-economic development of transport in 2011 and the tasks for 2012 and until 2014), MOT, Moscow.

MOT (2012b), Transportnaya Strategia Rossiiskoi Federacii na Period do 2030 Goda (Transport Strategy of the Russian Federation until 2030), MOT, Moscow.

Nord-News agency (2013), "Skorost Gruzovih Poezdov na Seti Zheleznih Dorog v Janvare 2012 Goda Virosla" (The Speed of Freight Trains Increased in January, 2013), http://nordnews.ru/news/2013/02/04.

OECD (2011), OECD Economic Surveys: Russian Federation, OECD Publishing.

OECD (2014), Review of SME and Entrepreneurship Issues and Policies in the Russian Federation, OECD Publishing, forthcoming.

Okulov, V. (2011), "The Russian Ministry of Transport initiatives in air cargo transportation development on domestic and international markets", paper presented at the II AirCargo Forum, Moscow.

OPORA (2012), The entrepreneurship climate in Russia: Index of OPORA-2012, Moscow.

Public Opinion Foundation (2013), Survey of public opinion. 


\section{ECO/WKP(2015)11}

Rosmorport (2012), Strategy of the sea port infrastructure development of Russia until 2030, Rosmorport, Moscow.

Sobol, E. (2012), “Discaunter ne Letit” (The Discounter Won’t Fly), Vedomosti 30.11.2012, Moscow.

Strategy Partners Group (2013), “CEO Agenda Survey”, SGP, Moscow.

World Bank (2013), Doing Business 2013, WB, Washington, DC.

World Bank (2013), Doing Business 2014, WB, Washington, DC.

World Economic Forum (2013), The Global Competitiveness Report 2013-14, WEF,Geneva.

World Economic Forum (2012), The Global Enabling Trade Report 2012, WEF, Geneva. 
ECO/WKP(2015)11

\section{Annex 1.A1 \\ Economic impact of improving transport infrastructure in Russia: Results of the computable general equilibrium model}

The SUST-RUS is a regional computable general equilibrium model of the Russian economy (Sust-Rus, 2013). The model includes the representation of the microeconomic behaviour of 32 industries, three types of households (high, medium and low income groups) and a regional government in each of 7 regions (federal districts) of the Russian Federation, as well as federal governments. The model represents regional economic developments, as well as interregional and international trade linkages. It models continuous substitution between capital, labour, energy and material inputs in the case of firms, and between different consumption goods in the case of households.

\section{Firms}

The behaviour of the production sectors is based on the profit-maximisation principle and is captured by the behaviour of the representative firm. Sectoral return to capital is associated with the costs and structure of their intermediate inputs and factor inputs. Intermediate inputs of the firms include energy, various commodities and services. Factor inputs of the firms include physical capital and labour. At each time period, the instantaneous behaviour of the sectors is based on the minimisation of the production costs for a given output level under the sector's technological constraint. The production technology of the sector is represented by the nested Constant Elasticity of Substitution (CES) functions.

\section{Households}

The behaviour of the households is based on the utility-maximisation principle. A household's utility is associated with the level and structure of its consumption. Each household spends its consumption budget on services and goods in order to maximise its satisfaction from the chosen consumption bundle. Households have substitution possibilities between different consumption commodities. Households in the model receive their income in the form of wages, capital rent, unemployment benefits and other transfers (pensions and other social transfers) from the federal government.

\section{Governments}

The governmental sector collects taxes, pays subsidies and makes transfers to households, production sectors and to the rest of the world. Tax revenues are shared by the national and regional governments according to the certain rates determined from the base year data. The federal and regional governments consume a number of commodities and services, where the optimal governmental demand is determined according to the maximisation of the governmental consumption utility function.

\section{Data sources}

The benchmark dataset is a multiregional Social Accounting Matrix (SAM), where each regional SAM represents economy of a federal district of the Russian Federation. All regional SAMs are interconnected by trade and income flows. The model is calibrated using 1995 and 2003 Russian symmetric input-output tables, System of National Accounts 2001-08 and Russian interregional trade database. Base year is 2006 as dictated by data calibration availability.

\section{Focus on Russian regions and the role of the transport sector}


Federal Districts (FD) of the Russian Federation are highly differentiated. Gross Regional Product is the highest in the Central FD. This is the most densely populated region with 52 persons per square km, which is 6 times bigger than the country average, and with most diversified economy. Far East FD is the least developed region the biggest territory but the smallest GRP and population. South FD is the poorest region with GRP per capita 2.3 times less than the country average. Urals FD has biggest GDP per capita, it is a manufacturing heart of the Russian economy and it is rich in natural resources with $66.7 \%$ of Russian oil reserves and $77.8 \%$ of gas reserves.

Transport sector amounts to $8 \%$ of total country's production and similar share of capital use, but $10 \%$ of total employment, according to 2006 data used for model calibration. Transport sector is most intensive in medium skill workers, employing $12 \%$ of country total, compared with only $5.5 \%$ for high skill workers and $7.8 \%$ for low skill workers. Demand from other production sectors accounts for $44 \%$ of total transport services, transportation of goods from producer to consumers for $16 \%$, households use for $25 \%$, government use for $3 \%$ and export for $12 \%$. Import penetration of transport is very low. Importance of transport regions varies strongly with a share of transport sector in GRP (employment) ranging from 6.6\% $(8 \%)$ in the Central FD to $11.9 \%$ (13.3\%) in the Far East FD.

\section{Policy scenario: transport sector efficiency improvement}

The policy scenario mimics increase in overall efficiency improvement in the transport sector. It is assumed that all types of labour, capital and energy across the country become $10 \%$ more productive. Factor productivity rise of $10 \%$ in transport sector results in GDP increase of $0.8 \%$ from the benchmark value. This positive effect could be traced on the regional level. The poor or underdeveloped regions tend to benefit from largest increase in GRP, and the opposite is true for two richest regions Central FD and Urals FD. This means that improvement in efficiency contributes to regional convergence (Figure A1.1).

Figure A1.1. Impact of $10 \%$ increase in transport sector efficiency on Federal Districts

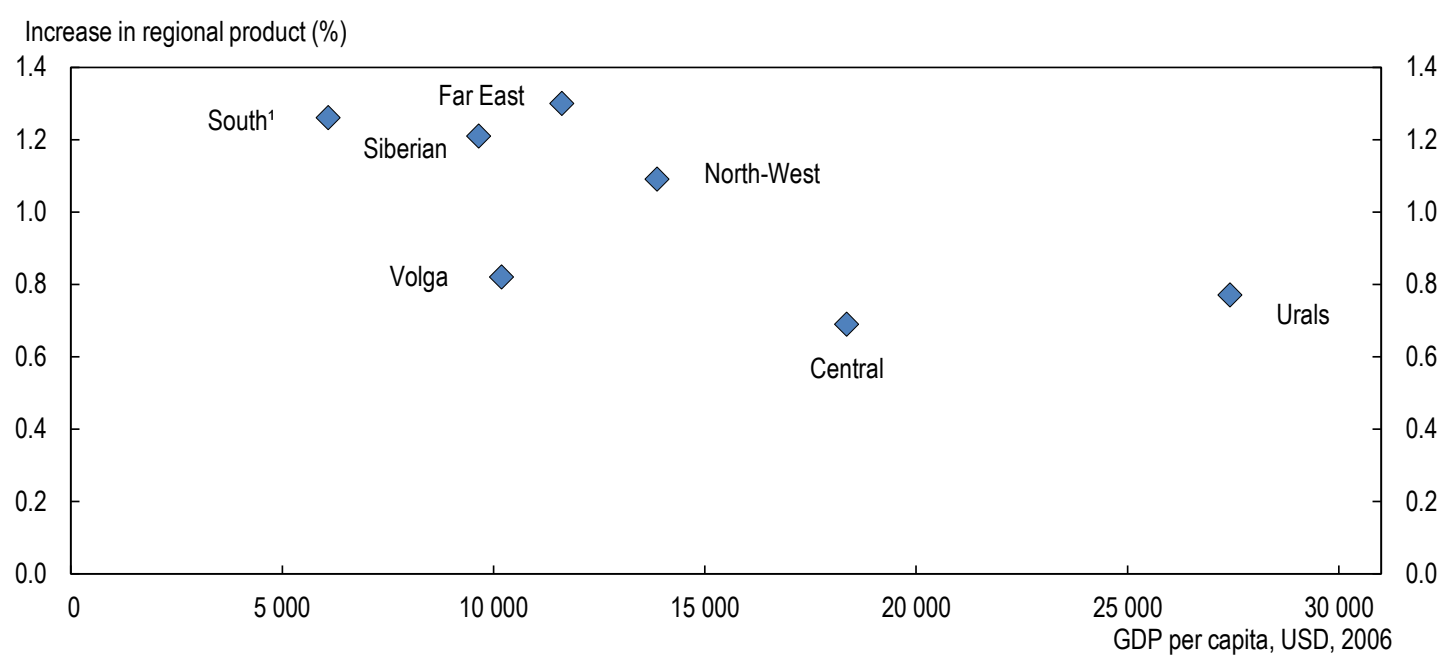

1. South Federal District is in the boarders of 2006, previous to its division between South and North Caucasian Federal Districts.

Source: SUST-RUS model calculations.

Transport efficiency has also an impact on sectoral composition of output. Apart from transport sector itself, manufacturing is the biggest winner from efficiency improvement, while extraction sectors gain the least (Figure A1.2). Improvements in transport efficiency contribute therefore to economic diversifications. 
Figure A1.2. Impact of $10 \%$ increase in transport sector efficiency on sectors

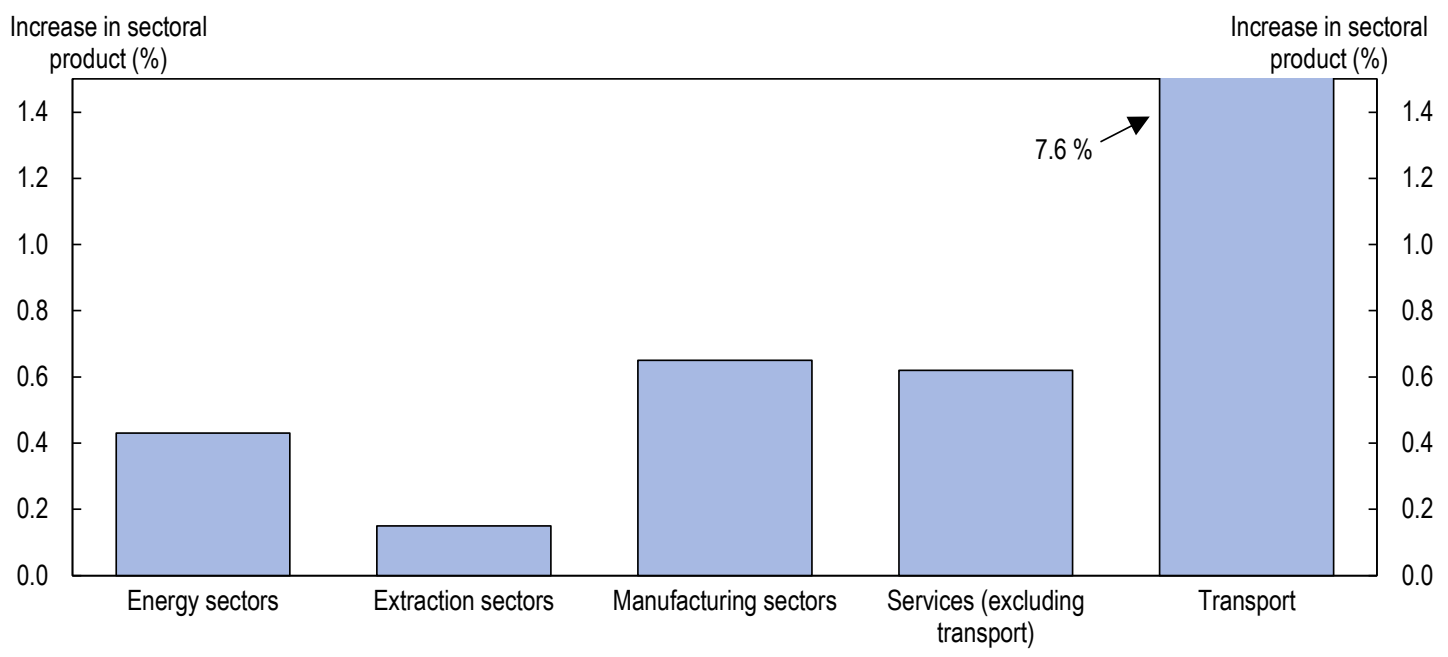

Source: SUST-RUS model calculations.

These positive effects are strengthened if efficiency improvements are supported by transport oriented investment. For example, increase in transport infrastructure spending, which corresponds to the current official transport development programme and amounts to $1.8 \%$ of total national investment, would increase the overall positive impact to $2.1 \%$ of GDP.

\section{BIBLIOGRAPHY}

Sust-Rus (2013), Spatial-economic-ecological model for the assessment of sustainability policies of the Russian Federation, Final Publishable Summarsmallery Report, Moscow. 


\section{WORKING PAPERS}

The full series of Economics Department Working Papers can be consulted at www.oecd.org/eco/workingpapers

1192. Improving the business climate in Russia

(March 2015) by Arthur Radziwill and Yana Vaziakova

1191. Determinants of female entrepreneurship in India

(March 2015) by Arnaud Daymard

1190. The Changing Role of The Exchange Rate For Macroeconomic Adjustment

(March 2015) by Patrice Ollivaud, Elena Rusticelli and Cyrille Schwellnus

1189. Boosting productivity in Russia: skills, education and innovation

(March 2015) by Lilas Demmou and Andreas Wörgötter

1188. Boosting growth and reducing informality in Mexico

(March 2015) by Sean Dougherty

1187. The conduct of monetary policy in the future: instrument use

(March 2015) by Kei-Ichiro Inaba, Rory O'Farrell, Łukasz Rawdanowicz and Ane Kathrine Christensen

1186. A constant market share analysis of Spanish goods

(February 2015) by Alberto Gonzalez Pandiella

1185. Raising the economic participation of women in India - a new growth engine?

(February 2015) by Piritta Sorsa

1184. Improving health outcomes and health care in India

(January 2015) by Isabelle Joumard and Ankit Kumar

1183. Challenges and opportunities of India's manufacturing sector

(January 2015) by Isabelle Joumard, Urban Sila and Hermes Morgavi

1182. The heterogeneity of product market regulations

(December 2014) by Jean-Marc Fournier

1181. Implicit regulatory barriers in the EU single market: new empirical evidence from gravity models

(December 2014) by Jean-Marc Fournier, Aurore Domps, Yaëlle Gorin, Xavier Guillet and Délia Morchoisne

1180. Can pro-growth policies lift all boats? An analysis based on household disposable income (December 2014) by Orsetta Causa, Alain de Serres and Nicolas Ruiz

1179. Empirical evidence on the effects of environmental policy stringency on productivity growth (December 2014) by Silvia Albrizio, Tomasz Koźluk and Vera Zipperer

1178. The Indicators of the Economic Burdens of Environmental Policy Design - Results from the OECD Questionnaire

(December 2014) by Tomasz Koźluk 
1177. Measuring Environmental Policy Stringency in OECD Countries-A Composite Index Approach (December 2014) by Enrico Botta and Tomasz Koźluk

1176. Do Environmental Policies Matter for Productivity Growth? Insights from new Cross-Country Measures of Environmental Policies

(December 2014) by Silvia Albrizio, Enrico Botta, Tomasz Koźluk and Vera Zipperer

1175. Making economic growth more socially inclusive

(December 2014) by Andrés Fuentes Hutfilter and Andreas Kappeler

1174. New tax and expenditure elasticity estimates for EU budget surveillance

(December 2014) by Robert W.R. Price, Thai-Thanh Dang and Yvan Guillemette

1173. Moving towards a more dynamic business sector in Spain

(November 2014) by Alberto Gonzalez Pandiella

1172. Better harnessing talent and knowledge to boost sustainable medium-growth in Spain (November 2014) by David Haugh and Ben Westmore

1171. The internet economy - regulatory challenges and practices

(November 2014) by Isabell Koske, Rosamaria Bitetti, Isabelle Wanner and Ewan Sutherland

1170. A revival of the private rental sector of the housing market? Lessons from Germany, Finland, the Czech Republic and the Netherlands

(October 2014) by Rik de Boer and Rosamaria Bitetti

1169. Secular stagnation: evidence and implications for economic policy

(October 2014) by Łukasz Rawdanowicz, Romain Bouis, Kei-Ichiro Inaba and Ane Kathrine Christensen

1168. Investment gaps after the crisis

(October 2014) by Christine Lewis, Nigel Pain, Jan Strasky and Fusako Menkyna

1167. Factors behind the decline in real long-term government bond yield

(October 2014) by Romain Bouis, Kei-Ichiro Inaba, Łukasz Rawdanowicz and Ane Kathrine Christensen 